\title{
THE RELATIONSHIP BETWEEN ENTREPRENEURSHIP AND NATIONAL COMPETITIVENESS
}

\author{
Khanh Hung DOAN \\ Doctoral School of Business Administration, Bucharest University of Economic \\ Studies, Bucharest, Romania \\ doankhanhhung.hat@gmail.com
}

Abstract: Currently, entrepreneurship is identified as an important factor for contributing to the economic development of the nation as well as the change of society. Entrepreneurship creates wealth, jobs, and economic growth in the country. Furthermore, a prominent feature of entrepreneurship is the enhancement of the country's competitiveness. Therefore, building and improving the nation's entrepreneurship is an urgent requirement to promote the country's competitiveness in the best way. In this paper, the relationship between national competitiveness and entrepreneurship is confirmed through quantitative analysis methods. In addition, the influence of entrepreneurship on the national competitiveness of countries in the world is also introduced. The specific objective of the study is to present two related indexes, namely the global entrepreneurship index and the global competitiveness index. Furthermore, through the assessment and comparison of these two indicators, the study also analyzes the relationship between entrepreneurship and national competitiveness. The paper's analysis is based on data covering 124 observed samples, provided by the Global Entrepreneurship Monitor in 2019 and the Global Competitiveness Report in 2019. Besides, analytical methods such as the graphic method, regression method were also performed. From this, it proved that there is existence a close relationship between the two indicators. The results show that the more entrepreneurship is raised, the more competitive the country will be. Therefore, the government needs to have policies that contribute to the development of national entrepreneurship. Herein, can contribute to supporting and promoting the competitiveness of the country. Finally, the presented results contribute to the promotion of studies assessing the influence of entrepreneurship and startups on national competitiveness. The paper ends with some discussion of the results and implications of the study.

Keywords: Global Entrepreneurship Index; Global Competitiveness Index; entrepreneurship, national competitiveness.

JEL Classification: $010 ; M 10 ; M 21$

\section{Introduction}

Currently, along with the development of the globalization process that is taking place in the world, the role of the competitiveness of each country is increasingly important. It shows the strength and capacity of each country. Herein, national competitiveness plays a role in promoting economic development, improving the country's labor productivity, attracting foreign investment, etc. Enhancing national 
competitiveness is an urgent requirement in the process of international integration and fierce competition among countries today. Thus, how to improve national competitiveness in the context of fierce competition of integration, while ensuring sustainable development is always a new issue that needs to be solved.

The researchers point out that the competitiveness of countries not only depends on external factors such as foreign investment capital, fluctuations in international markets, etc. but also depends on the internal factors of the country such as infrastructure, science, and technology level, human resources, human development level, etc. Among them, the entrepreneurship factor can be mentioned. Nowadays, more and more businesses are established and strongly developed thanks to the increasing mechanisms, policies, and entrepreneurship, especially in developing countries. A country with many active businesses will contribute to accelerating the transformation of the economy and the growth model of the economy. It will affect the country's competitiveness. Since then, the central role of entrepreneurship has been increasingly recognized. In addition, it is argued that entrepreneurship and innovation are driving competitiveness in all three aspects of the country's sustainable development (Herman, 2018). Therefore, it is necessary to consider the influence of entrepreneurship on national competitiveness. Governments need to consider the impact of entrepreneurship on national competitiveness specifically. Based on this, it can choose the best models of entrepreneurship development and contribute to improving national competitiveness. From there, countries accelerate economic growth, promote the start-up process and contribute to the existence and sustainable development.

This article will present a summary of the relationship and the influence of entrepreneurship on national competition. In addition, identification of key trends and gaps of entrepreneurship to the national competition is also introduced. After that, the study continues to make a general assessment of the influence of entrepreneurship on national competitiveness based on the analysis of the surveyed countries in the world.

The study was conducted based on data collected from the Global Entrepreneurship Monitor (GEM) in 2019 and data collected from the 2019 Global competitiveness report of the World Economic Forum (WEF). Finally, there are some conclusions and suggestions for improving research on the influence of entrepreneurship on national competitiveness. The paper is structured as follows: the first section provides a brief literature review of the studies, the second section explains the methodology used by the authors in this paper, and the third section the results of the research, while the final part is the conclusion and discussion of the research findings of the study.

\section{Literature Review}

\subsection{The relationship between entrepreneurship and national competition}

Currently, there is quite a lot of research on entrepreneurship as well as the characteristics and roles of entrepreneurship. Entrepreneurship has attracted the attention of both researchers and policymakers over the past decades (Al-Sartawi et al., 2019). It demonstrates the significant role of entrepreneurship in socioeconomic development. More and more research is being done on the aspects and features of entrepreneurship as well as the role and relationship of 
entrepreneurship on social and national factors and characteristics. Among them is the relationship between entrepreneurship and national competitiveness. Many scholars have emphasized the importance of economic competitiveness for business performance and economic development as well. However, few quantitative studies analyze the interrelationship between competitiveness and its role in increasing entrepreneurial activities at different stages of development (Rostami et al., 2019) as well as the purpose of improving the competitiveness of the countríes.

National competitiveness is a diverse concept and has many different characteristics. Therefore, entrepreneurship affects national competitiveness in many ways. Various studies (Szirmai et al., 2011), on the one hand, show that entrepreneurship can contribute to job creation, growth, and economic development through innovation. On the other hand, entrepreneurship contributes to economic growth (Korez-Vide and Tominc, 2016; Szabo and Herman 2012). Besides, Grilo and Thurik (2005) argued that entrepreneurship is at the heart of innovation, competitiveness, economic growth, and job creation. Accordingly, SMEs enterprises have an indispensable role in the process of improving competitiveness and establishing innovation systems. The entry of new small businesses puts constant pressure on existing enterprises to cut costs and increase productivity. At the same time, the growth of SMEs strengthens the economy's ability to create new jobs (Cuckovic and Bartlett, 2007). In addition, Fagerberg and Saprasert (2011) determined that innovative entrepreneurship is being considered a key element of the modern developed economy and is often associated with economic growth and technological progress (Al-Sartawi et al., 2019). However, the impact of entrepreneurship in the economy varies according to the characteristics of entrepreneurship, which in turn depends on the stage of economic development (Korez-Vide and Tominc, 2016; Herman, 2018). Douhan and Henrekson (2008) have shown a strong positive relationship between effective entrepreneurship and the innovation of the economy and its adaptability, thereby increasing the competitiveness of the economy. Thus, entrepreneurship, briefly reviewed in this paper, can be the driving force that enables the transformation of regional resources into regional and national competitiveness, added value, economic growth, and development. Practice proves that innovation and entrepreneurship are considered essential elements of national competitiveness (WEF, 2017).

In particular, understanding entrepreneurship is rooted in space making it a factor of national and regional competition (Nicolae et al., 2016). By research done in Romania, Nicolae et al. (2016) concluded that regional differences should be calculated when formulating national competition policy. Huggins and Williams (2011) also identified that less competitive regions are using to account issues related to entrepreneurship and business development as a tool to enhance regional competitiveness. Although there is a substantial policy in these areas in less competitive regions, entrepreneurship and entrepreneurship policy at the regional level is multidimensional, with policies ranging from those with economic or social orientation. However, research by Huggins and Williams (2011) also shows that there is a tension between using business policy as a tool to improve competitiveness in the region or to address economic and social disadvantages. Therefore, there is a need for more specific assessments of the role of entrepreneurship in regional competitiveness to limit possible drawbacks. 
At the national level, Aisyah and Saputra (2021) argued that in the current era of globalization, essential parts of entrepreneurship are the development of economic competitiveness to increase the welfare of the community, especially nations. Countries need to improve entrepreneurship and innovation, thereby contributing to the country's competitiveness (Aisyah and Saputra, 2021). Besides, the study of Korez-Vide and Tominc (2016) also stated that the developed business sector has a significant influence on economic growth and the success of national economies. It ultimately determines the competitiveness of that country (Korez-Vide and Tominc, 2016).

At the international level, Zahra and Dianne Hansen (200) also identify entrepreneurship as playing a role in promoting global competitiveness. In reality, it can be seen that entrepreneurship is increasingly attracting attention about its role in decision-making policies that can promote economic and social development. There has also been increased attentiveness on how entrepreneurs innovate and, therefore, in doing so, contribute to a higher level of international competition (Ferreira et al., 2017).

Herman (2018) explored the relationship between innovation, entrepreneurship, and national competitiveness at the EU level. From there, it aims to highlight how innovation and entrepreneurship can influence the level of competition and inclusive development in these countries. The results show that there is a significant difference between the group of countries with medium and low innovation performance and the group of countries with high and very high innovation performance in terms of competitiveness, innovation, entrepreneurship (Herman, 2018). Therefore, there is a need for concrete actions to improve the national competitiveness of EU countries through a level of creativity and entrepreneurship (Herman, 2018). In addition, the European Innovation Scoreboard report (EU, 2017) highlighted that the competitiveness of the European economy and the well-being of European citizens depend on innovation and entrepreneurship. Innovation and entrepreneurship increase productivity and promote economic growth, thereby enhancing the competitiveness of countries (EU, 2017). Reinforcing the point above, Fernandes et al. (2020) determined that innovation impacts competitiveness, and entrepreneurship shape the competitiveness of EU countries.

However, Amorós and Cristi (2008), in their study on the relationship between entrepreneurship and competitiveness of Latin American countries, determined that entrepreneurship has an inverse relationship with national competition and development. As the nation's economy recovers, entrepreneurship will decline. Besides, when entrepreneurs haven't a job, they only start a business (Amorós and Cristi, 2008). In more detail, Amorós and Cristi (2008) showed that for developing countries, competitiveness is directed more towards structural productive efficiency rather than enhancing the nation's entrepreneurial dynamics. Therefore, entrepreneurship may have less of a role to play in enhancing the country's competitiveness and may reduce the country's competitiveness.

\subsection{Global Entreperneurship Index}

The Global Entrepreneurship Index is a composite index that measures elements of a country's startup ecosystem. This index showcases the quality of entrepreneurship and support for the startup ecosystem. According to Ács et al. (2019), The Global entrepreneurship index identifies three levels for a country's 
score, including overall GEI score, scores for Individuals and Organizations, and pillar level. The GEM program began to examine and evaluate the role of entrepreneurship in national economic growth in 1999. Accordingly, the program has evolved into a worldwide survey of entrepreneurship. Since the start of the GEM project in 1999, GEM has recently surveyed and assessed entrepreneurship in more than 130 countries. In which, the main aim of the GEM project is to measure and define entrepreneurship in each country.

All GEM data is published and collected from the website www.gemconsortium.org, as well as GEM entrepreneurship research reports. This database is heavily used in entrepreneurship research by various researchers (Filculescu, 2016; Mrożewski and Kratzer, 2016; Harms and Groen, 2017) because this data allows for compare ratings between different countries in the world as well as have an in-depth analysis on the factors affecting entrepreneurship of each country. It helps to empirically address the characteristics of business at the national level as well as the realities of entrepreneurship in those countries. The Global Entrepreneurship Index (GEI), a composite index that measures both the quality of entrepreneurship in a country and the level and depth of the startup ecosystem that supports it, tends to be the highest in innovation-oriented economies and is positively correlated with the level of development (GEDI, 2017). In addition, this index represents an expansive view of the entrepreneurial phenomenon and facilitates the identification of its strengths and weaknesses, opening the door to policy modification and the promotion of appropriate actions towards entrepreneurship.

The Global Entrepreneurship Index measures the development of entrepreneurship comprehensively through the following key indicators:: Product Innovation, Process Innovation, High Growth, Opportunity Perception, Startup Skills, Risk acceptance, Networking, Cultural support, Technology Absorption, Human Capital, Competition, Internationalization, Risk Capital (Ács et al., 2019).

The entrepreneurship research results of the Global Entrepreneurship Report have helped leaders and researchers have an overview and detailed view of entrepreneurship not only of each country studied but also of the whole world. From there, they can propose solutions and policies that contribute to promoting entrepreneurship in their country.

\subsection{Global Competitiveness Index}

The Global Competitiveness Report is an annual bulletin published by the World Economic Forum (WEF), first released in 1979. The 2019-2020 report covers 141 economies, that major and prominent economy (Schwab, 2019). This report aims to assess the ability to provide a high or low level of prosperity for the population in each country. In particular, this report publishes the "Global Competitiveness Index" (GCl) to measure the trends of institutions, policies, factors that make up the current state, and the limits of economic prosperity.

Since 2004, the global competitiveness report ranks countries based on a global competitiveness index. It is a highly comprehensive index to measure national competitiveness, which captures the national macroeconomic and microeconomic foundations. (Sala-iMartin et al., 2011). GCl was developed by Xavier Sala-iMartin and Elsa V. Artadi (2004). Currently, GCl is widely cited and used in many documents for many academic studies as well as many articles in prestigious journals. The Global Competitiveness Report is based on the top four factors considered to affect a country's competitiveness index: inflation, infrastructure, 
skilled labor, and level of corruption. Each year, the WEF ranks approximately 130 countries globally in the Global Competitiveness Index and publishes that figure in the Global Competitiveness Report.

The economic data of the report are collected from the countries participating in the survey (hard data), and the results are taken from the investigation of enterprises and economic experts (soft data). This report has been made for decades and shows an overview and comprehensive picture of the strengths and weaknesses of the national economies, thereby identifying opportunities and challenges themselves. WEF ratings also reflect factors affecting a country's business environment, which are also fundamental to sustainable economic growth.

However, in terms of reliability, many experts now say that the report is only relative and does not affect investors' confidence. In addition, whether the information and input materials used for analysis are standard or not is still a matter to consider, but this is the basis for governments to refer to.

In addition, this report has been built on more than 110 variables, of which twothirds come from the Executive Opinion Survey, and one-third come from publicly available sources such as the United Nations. Based on this, the variables are organized into twelve pillars, with each pillar representing an area considered to be an important determinant of competitiveness. - Institutions.

- Appropriate infrastructure.

- Stable macroeconomic framework.

- Good health and primary education.

- Higher education and training.

- Efficient goods markets.

- Efficient labor markets.

- Developed financial markets.

- Ability to harness existing technology.

- Market size-both domestic and international.

- Production of new and different goods using the most sophisticated production processes.

- Innovation.

All these 12 pillars interact and influence each other. Weaknesses in one subject often harm others. In general, the pillars are essential to a certain extent for the economy. However, because of the different stages of development of countries, they affect them in different ways.

\section{Methodologies}

\subsection{Research purposes}

The main aim of the study is to test the hypothesis that national entrepreneurship has a positive influence on national competitiveness. In addition, through the evaluation and comparison of two important criteria that is the Global Entrepreneurship Index and the Global Competitiveness Index by statistical analysis methods, the article also shows the relationship of the two indexes above.

\subsection{Data collection}

The global entrepreneurship index data of this study were collected based on GEM (2019) data. The total number of observed samples in the GEM data for countries 
is 137 , corresponding to 137 different countries and territories. Besides, National competitiveness data is also collected based on the data of the World Economic Forum (WEF) 2019, Global Competitiveness Report. The total number of countries and territories analyzed on the Global competitiveness index in 2019 includes 141 countries and territories, corresponding to 141 observed samples collected.

Due to the difference in the number of observed samples between different countries in the above reports, we have analyzed and used the observed samples countries and territories that share the data of both reports. The total number of observations collected for that study was 124 observations. The author will use these 124 observed samples to analyze in the study. The results of descriptive statistics Entrepreneurship index and National competitiveness index collected from GEM and WEF are shown in Table 1. The total number of observed samples is 124 samples. The GEI mean of 35,061 was rated as average. Besides, the average value of the national competitiveness index is 61,728 , which is assessed at a high level.

Table 1: Descriptive Statistics

\begin{tabular}{|l|c|r|r|r|c|}
\hline & N & Minimum & Maximum & Mean & $\begin{array}{c}\text { Std. } \\
\text { Deviation }\end{array}$ \\
\hline GEI & 124 & 8.8 & 86.8 & 35.061 & 19.4923 \\
\hline GCl & 124 & 35.1 & 84.8 & 61.728 & 11.9410 \\
\hline Valid N (listwise) & 124 & & & & \\
\hline
\end{tabular}

Source: Author's own research results.

\subsection{Data analysis}

The analytical method used in this paper is the graph analysis method and the regression analysis method used to analyze the influence of entrepreneurship on the country's competitiveness. Regression is an analytical method to see how the independent variable affects the dependent variable when the independent variable changes. Here, the study aims to examine how entrepreneurship affects national competitiveness. If the Sig. value of the F-test is statistically significant (Sig. value < 0.05), that is, the model built is significant. In addition, the results Sig. value of the t-test corresponding to the GEI independent variable is statistically significant (Sig. value < 0.05), that is, the GEI independent variable has a statistically significant effect on the $\mathrm{GCl}$ dependent variable. The steps of data processing, descriptive statistics, graph analysis, and regression analysis were performed using SPSS 23.0 software.

\section{Results}

\section{Influence of entrepreneurship on national competitiveness}

Firstly, the study was conducted using a graphical method to determine the relationship between the two factors: entrepreneurship and national competition. The graph showing the relationship between entrepreneurship and the country's competitiveness is shown in figure 1. Through figure 1, the arrangement of observation points on the graph can be observed. There is a relationship between entrepreneurship and national competition. That relationship is a positive one. As the value of GEl increases, there is an increase in the value of $\mathrm{GCl}$. Besides, the 
value of $\mathrm{GCl}$ changes when there is a change of $\mathrm{GEl}$ is homogenous. We can draw a clear regression line located in the center of the points on the graph. This result shows that $\mathrm{GCl}$ and $\mathrm{GEI}$ have a linear relationship with each other.

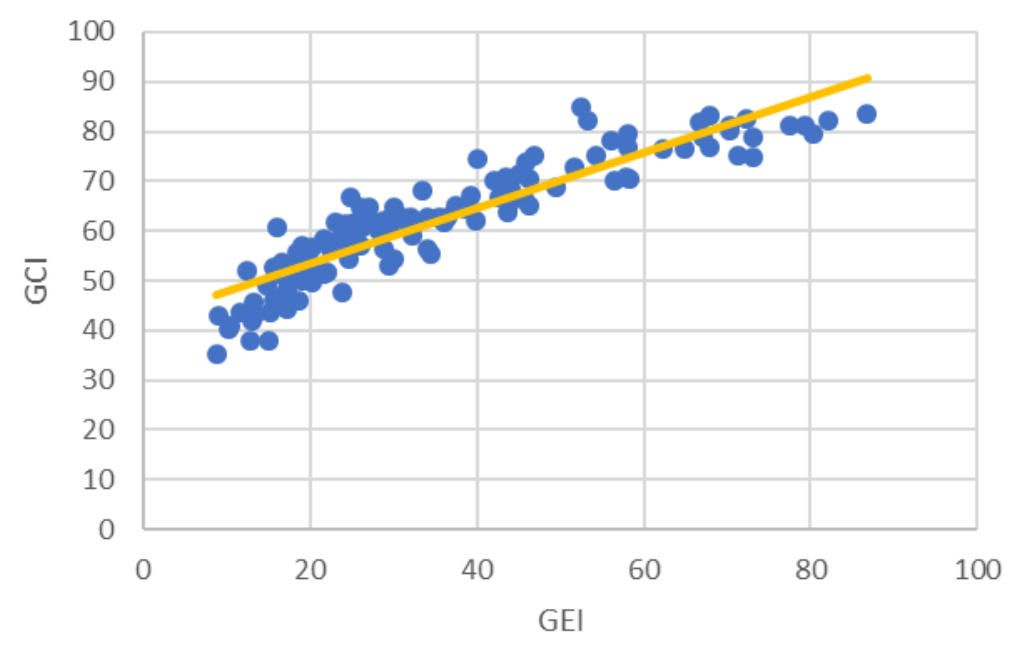

Figure 1: Correlogram between GEI and GCl in 2019 Source: Author's own research results.

To conduct regression analysis to determine the relationship between entrepreneurship and national competitiveness, the Pearson correlation coefficient was studied and used to analyze the statistical relationship between two variables, $\mathrm{GCl}$ and $\mathrm{GEl}$. The analysis results in Table 2 show that the two indexes $\mathrm{GCl}$ and GEI have a close and direct correlation with each other (Pearson $=0.911$ ). Besides, this Pearson correlation coefficient is also statistically significant with the significance level of 0.05 (Sig. value $<0.05$ ).

Table 2: Correlations

\begin{tabular}{|l|l|l|l|}
\hline \multicolumn{2}{|c|}{} & GEI & GCI \\
\hline \multirow{2}{*}{ Pearson Correlation } & GEI & 1 & $0.911^{* *}$ \\
\cline { 2 - 4 } & GCl & $0.911^{* *}$ & 1 \\
\hline \multirow{2}{*}{ N } & GEI & 0.000 & 0.000 \\
\cline { 2 - 4 } & GCl & 0.000 & 0.000 \\
\hline & GEI & 124 & 124 \\
\cline { 2 - 4 } & GCl & 124 & 124 \\
\hline
\end{tabular}

${ }^{\star *}$. Correlation is significant at the 0.01 level (2-tailed).

Source: Author's own research results.

To analyze the influence of the Global Entrepreneurial Index (GEI) on the Country Competitiveness Index $(\mathrm{GCl})$, the study conducted a regression analysis based on the OLS econometric regression model. The regression model has the following formula:

$$
\mathrm{GCl}=\beta_{0}+\beta_{1} \cdot \mathrm{GEI}+\varepsilon(1)
$$


The results of the analysis of the conditions of the carried out econometric model in table 4 show that the model (1) built above has a significance level of 0.05 because the Sig value. of the F-test is statistically significant (Sig. value $<0.05$ ).

Table 3: Model Summaryb

\begin{tabular}{|c|c|c|c|c|c|c|c|c|c|c|}
\hline \multirow[b]{2}{*}{ Model } & \multirow[b]{2}{*}{$\mathbf{R}$} & \multirow[b]{2}{*}{$\begin{array}{c}\mathbf{R} \\
\text { Square }\end{array}$} & \multirow[b]{2}{*}{$\begin{array}{c}\text { Adjusted } \\
\mathbf{R} \\
\text { Square }\end{array}$} & \multirow{2}{*}{$\begin{array}{c}\text { Std. } \\
\text { Error of } \\
\text { the } \\
\text { Estimate }\end{array}$} & \multicolumn{5}{|c|}{ Change Statistics } & \multirow[b]{2}{*}{$\begin{array}{l}\text { Durbin- } \\
\text { Watson }\end{array}$} \\
\hline & & & & & $\begin{array}{c}\text { R } \\
\text { Square } \\
\text { Change }\end{array}$ & $\begin{array}{c}F \\
\text { Change }\end{array}$ & df1 & df2 & $\begin{array}{l}\text { Sig. F } \\
\text { Change }\end{array}$ & \\
\hline 1 & $0.911^{\mathrm{a}}$ & 0.830 & 0.829 & 4.9369 & 0.830 & 597.596 & 1 & 122 & 0.000 & 1.908 \\
\hline
\end{tabular}

a. Predictors: (Constant), GE

b. Dependent Variable: GCI

Source: Author's own research results.

Table 4: ANOVA ${ }^{a}$

\begin{tabular}{|l|l|r|r|r|r|c|}
\hline \multicolumn{2}{|c|}{ Model } & Sum of Squares & \multicolumn{1}{c|}{ df } & Mean Square & \multicolumn{1}{c|}{ F } & Sig. \\
\hline \multirow{3}{*}{1} & Regression & 14564.939 & 1 & 14564.939 & 597.596 & $0.000^{\mathrm{b}}$ \\
\cline { 2 - 7 } & Residual & 2973.452 & 122 & 24.373 & & \\
\cline { 2 - 7 } & Total & 17538.391 & 123 & & & \\
\hline
\end{tabular}

a. Dependent Variable: $\mathrm{GCl}$

b. Predictors: (Constant), GEI

Source: Author's own research results.

Besides, the analysis results in table 3 also show that the value of $R^{2}=0.830$, that is, the change of GEI variable explains $83.0 \%$ of the change of $\mathrm{GCl}$. The results of the Durbin-Watson test (value is 1.908) show that the model does not have autocorrelation.

From that, the regression analysis based on the OLS model is estimated as shown in Table 5. In which, the regression results for the values of the independent variable (entrepreneurship) and the dependent variable (competitiveness) (see table 5):

$$
\mathrm{GCl}=42.155+0.558 \times \mathrm{XEI}(2)
$$

The results show that the coefficient of the GEI variable is statistically significant with a significance level at 0.05 (Sig. value $<0.05$ ). In addition, the analysis results also show that when the dependent variable is the GEI changes by 1 unit, $\mathrm{GCl}$ will change by 0.558 units.

Table 5: Coefficients ${ }^{\mathrm{a}}$

\begin{tabular}{|c|c|c|c|c|c|c|c|c|}
\hline & \multirow{2}{*}{ Model } & \multicolumn{2}{|c|}{$\begin{array}{l}\text { Unstandardized } \\
\text { Coefficients }\end{array}$} & \multirow{2}{*}{$\begin{array}{c}\text { Standardized } \\
\text { Coefficients }\end{array}$} & \multirow[t]{2}{*}{$\mathbf{t}$} & \multirow{2}{*}{ Sig. } & \multicolumn{2}{|c|}{$\begin{array}{c}95.0 \% \\
\text { Confidence } \\
\text { Interval for B } \\
\end{array}$} \\
\hline & & B & $\begin{array}{l}\text { Std. } \\
\text { Error }\end{array}$ & & & & $\begin{array}{l}\text { Lower } \\
\text { Bound }\end{array}$ & $\begin{array}{l}\text { Upper } \\
\text { Bound }\end{array}$ \\
\hline \multirow{2}{*}{1} & (Constant) & 42.155 & 0.915 & & 46.059 & 0.000 & 40.343 & 43.967 \\
\hline & GEI & 0.558 & 0.023 & 0.911 & 24.446 & 0.000 & 0.513 & 0.603 \\
\hline
\end{tabular}

a. Dependent Variable: GCI

Source: Author's own research results. 


\section{Discussion and Conclusion}

Entrepreneurship now plays a significant role in the goals and strategies of countries. From there, it can contribute to develop of the country and enhance its competitiveness of that country. By improving the country's competitiveness, it can help the country develop more sustainably and efficiently, as well as contribute to attracting foreign investment, improving the prestige and efficiency of the country on the international market. Therefore, it is momentous to focus on developing the nation's entrepreneurship.

The study confirmed the hypothesis of a positive relationship between entrepreneurship and competitiveness. The results have shown that through statistical analysis methods, mathematical analysis has determined that there is existence a close relationship between the two indexes, namely the national competitiveness index and the global entrepreneurship index. Besides, entrepreneurship has a positive impact on the competitiveness of the country. This influence is quite good. When entrepreneurship increases by one unit, it will increase national competitiveness by 0.558 units. In addition, the results of graph analysis on the relationship between entrepreneurship and national competitiveness also show that the influence of entrepreneurship on national competitiveness is quite uniform. The results of the regression line coincide with the points on the graph, so entrepreneurship and national competitiveness have a linear relationship with each other. This result has implications for policymakers of countries to develop policies on entrepreneurship with the goal of developing national competitiveness in accordance with the realities of their country.

In addition, this study has certain limitations related to the nature and characteristics of the data used for analysis in this paper. The samples of the study are based on a global structured survey conducted by GEM and WEF. However, the number of observed samples used in the study is still modest, not covering all countries in the world. Besides, the study can not go into the deep analysis of the effects of entrepreneurship on national competitiveness because it was based on available data. Future studies can go deeper into the measure of factors in the country's competitiveness. Furthermore, it may be possible to use a combination of many different criteria to assess the impact on the country's competitiveness in a more comprehensive way.

\section{References}

1. Ács, Z.J., Szerb, L., Lafuente, E. and Márkus, G. (2019). Global entrepreneurship and development index 2019. The Global Entrepreneurship and Development Institute, Washington, D.C., USA.

2. Aisyah, H. and Saputra, N. (2021). Innovation And Entrepreneurship For Competitiveness In The ASEAN: An Empirical Analysis. Jurnal Ekonomi Pembangunan, 19(01), pp. 57-69.

3. Al-Sartawi, A.M.M., Badawi, S., Hanoon, A., Hamdan, A., Reyad, S. and Razzaque, A. (2019). Entrepreneurship Education and Country Competitiveness: Avenues for Future Research in the Arab Countries. In European Conference on Innovation and Entrepreneurship (pp. 59-XXIV). Academic Conferences International Limited. 
4. Amorós, J.E. and Cristi, O. (2008). Longitudinal analysis of entrepreneurship and competitiveness dynamics in Latin America. International Entrepreneurship and Management Journal, 4(4), pp. 381-399.

5. Borozan, Đ. (2009). Enhancing Regional Competitiveness Through The Entrepreneurship Development. Interdisciplinary Management Research, 5.

6. Cuckovic, N. and Bartlett, W. (2007). Entrepreneurship and competitiveness: the Europeanisation of small and medium-sized enterprise policy in Croatia. Southeast European and Black Sea Studies, 7(1), pp. 37-56.

7. Douhan, R., and Henrekson, M. (2008). Productive and destructive entrepreneurship in a political economy framework. Stockholm, Sweden; Research Institute of Industrial Economics; IFN Working Paper (2008) No. 761.

8. European Union (EU) (2017). European Innovation Scoreboard 2017. [Online] Available: http://ec.europa.eu/DocsRoom/documents/24829. [22 Nov 2021]

9. Fagerberg, J. and Sapprasert, K. (2011). National innovation systems: the emergence of a new approach. Science and public policy, 38(9), pp. 669-679

10. Fernandes, C.I., Veiga, P.M., Ferreira, J.J., Teixeira, S.J. and Rammal, H.G. (2020). The Impact of Innovation and Entrepreneurship on Competitiveness. In Technological Innovation and International Competitiveness for Business Growth (pp. 97-117). Palgrave Macmillan, Cham.

11. Ferreira, J.J., Fernandes, C.I. and Ratten, V. (2017). Entrepreneurship, innovation and competitiveness: what is the connection?. International Journal of Business and Globalisation, 18(1), pp. 73-95.

12. Filculescu, A. (2016), The heterogeneous landscape of innovation in female-led businesses - cross-country comparisons, Management \& Marketing. Challenges for the Knowledge Society, Vol. 11, No. 4, pp. 610-623.

13. Grilo, I. and Thurik, R. (2005). Entrepreneurial engagement levels in the European Union.

14. Harms, R. and Groen, A. (2017). Loosen up? Cultural tightness and national entrepreneurial activity. Technological forecasting and social change, 121, pp. 196204.

15. Herman, E. (2018). Innovation and entrepreneurship for competitiveness in the EU: an empirical analysis. In Proceedings of the International Conference on Business Excellence (Vol. 12, No. 1, pp. 425-435). Sciendo.

16. Huggins, R. and Williams, N. (2011). Entrepreneurship and regional competitiveness: the role and progression of policy. Entrepreneurship \& Regional Development, 23(9-10), pp. 907-932.

17. Korez-Vide, R. and Tominc, P. (2016). Competitiveness, Entrepreneurship and Economic Growth. In Competitiveness of CEE Economies and Businesses (pp. 2544). Springer International Publishing.

18. Mrożewski, M. and Kratzer, J. (2017). Entrepreneurship and country-level innovation: Investigating the role of entrepreneurial opportunities. The Journal of Technology Transfer, 42(5), pp. 1125-1142.

19. Nicolae, M., Ion, I. and Nicolae, E. (2016). Regional differences in entrepreneurial perceptions and implications for the Romanian competitiveness policy. Management \& Marketing, 11(1).

20. Rostami, N., Khyareh, M.M. and Mazhari, R. (2019). Competitiveness, entrepreneurship, and economic performance: Evidence from factor-, efficiency-, and innovation-driven countries. Economic Annals, 64(221), pp. 33-64. 
21. Sala-iMartin, X., Bilbao-Osorio, B. and Blanke, J. (2011). The Global Competitiveness Report 2011-2012, World Economic Forum.

22. Sala-i-Martin, X. and Artadi, E. V. (2004). The Global Competitiveness Index. Global Competitiveness Report. In World Economic Forum.

23. Schwab, K. (2019), The Global Competitiveness Report 2019, World Economic Forum.

24. Szabo, Z.K. and Herman, E. (2012). Innovative entrepreneurship for economic development in EU. Procedia Economics and Finance, 3, pp. 268-275.

25. Szirmai, A., Naudé, W. and Goedhuys, M. (Eds.) (2011). Entrepreneurship, innovation, and economic development. Oxford University Press.

26. World Economic Forum (2017). The Global Competitiveness Report 2017. Geneva: World Economic Forum.

27. Zahra, S.A. and Dianne Hansen, C. (2000), Privatization, Entrepreneurship, And Global Competitiveness In The 21st Century, Competitiveness Review, 10(1), pp. 83-103 